\title{
Køn og ligestilling fra Humboldt til Mickey Mouse Universitet
}

\section{Af Hilda Rømer Christensen}

\section{“ $U_{\text {rip }}$} mennesket finder gennem og $i$ sig selv, indsigten $i$ den rene videnskab. Til denne selvakt $i$ egentlig forstand er fribed og udviklende ensombed nødvendig, og af disse to punker folger tillige bele universiteternes ydre organisation."

(Humboldt 1809)

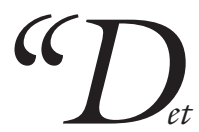
universiteternes uafhengighed og autonomi sikrer at højere uddannelse og forskningssystemer kontinuerligt tilpasser sig de forandrede behov, samfundets krav og fremme af den videnskabelige viden.”

(The Bologna Declaration of 19 June 1999. Joint Declaration of the European Ministers of Education.)

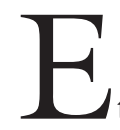

træt dødsleje.

Sådan betegnede Forskerforum det klassiske universitets ufrivillige afskaffelse i foråret 2003 med vedtagelsen af en række vidtrækkende love for universitets- og forskningsområdet. ${ }^{3}$ I løbet af lovgivningsprocessen blev der gjort adskillige forsøg på at mobilisere universitetsverdenen ved møder og underskriftindsamlinger, ligesom universitetsfolket løbende i offentligheden har ytret sig imod de nye toner og tider. Men alt sammen forgxves.

Op til og under lovens vedtagelse havde dagspressen stort set mistet interessen. Kun en uhellig alliance af kritiske røster, bestående af en frygtløs redaktør af bladet Forskerforum og af Dansk Folkepartis Jesper Langballe, var tilbage i et landskab, der ellers var præget af resignation. Ingen dramatik, ingen trusler om besættelser og strejker, ingen slagord og ingen eller næsten ingen uoverlagte ordvekslinger. I skrivende stund er institutionerne allerede langt inde nye forhandlinger og omstil- 
lingsprocesser. Logikken synes at være møntet på det, der i moderne flysprog bliver kaldt for damage control, at begrænse skaderne eller at få det bedste ud af en dårlig situation.

Hvad skyldes denne træthed og resignation? At universitetsdemokratiet, i form af Styrelsesloven fra 1971, engang den mest moderne og demokratiske af sin art, allerede er undermineret? Den reviderede universitetslov fra 1993 indskrænkede universitetsdemokratiet og afskaffede den vedtagne UFA norm og VIPernes ret til at bruge $50 \%$ af arbejdstiden til forskning. Samtidig er administrations- og undervisningsopgaver taget til i takt med at universitetet har udviklet sig fra eliteuniversitet med bare 10.000 studerende i 1960 til højere masseuddannelsesinstitutioner med 100.000 studerende ved årtusindskiftet.

En anden og mere delikat tese går ud på at nogle, måske endda mange, sådan i al stilfærdighed, og når det nu endelig skal være, ser muligheder i de nye tider. F.eks. for at blive ansatte ledere, for at profilere egen forskning og for at slippe af med universiteternes støvede image. Denne usikkerhed og tøvende forandringsvilje har måske i virkeligheden været regeringens mest pålidelige forbundsfælle i det, der er kaldt den største universitetsreform i 700 år. For universitetsansatte med ligestillings- og kønsforskningsinteresser, er det såmænd også ganske fristende at lade sig forføre af retorikken om fleksibilitet og central styring. Temaer som ligestilling og kønsforskning sætter med andre ord de latente paradokser og ambivalenser i de nye strukturer på spidsen.

Den nye universitetslov gør det således muligt at sætte ligestilling på dagsordenen oppefra på universiteter og i forskningen. $\mathrm{Nu}$ kan universiteternes autonomi og selvstyre ikke længere bruges som bolværk og undskyldning for mere end 100 års diskrimination og passivitet. Handlekraftige universitetsledelser får med de aktuelle universitets- og ligestillingslove mulighed for at omsætte festtalernes retorik om ligestilling i de nye udviklingskontrakter. Og for at prioritere initiativer på alle niveauer indadtil i organisationen, ved f.eks. at opfylde kravet om ligelig kønsfordeling i offentlige bestyrelser og udvalg og ved at tænke køn og ligestilling ind i satsningsområder og forskning, således som den nye mainstreamingstrategi tilsiger det. Teoretisk set har et tværfagligt forskningfelt som kønsforskning også tiden for sig som følge af den mere åbne og fleksible struktur, som er indeholdt i de nye studiestrukturer.

Nyere forskning peger på, at de markedsrettede universiteter i USA har været gode til at praktisere ligestilling og at inkludere kønsforskning i universitetsprofilerne. Den anglo-amerikanske forskningskultur, præget af en pragmatisk og empirisk orientering, har haft lettere ved dette sammenlignet med universiteterne på det europæiske kontinent. Her har de universitære kulturer i højere grad været præget af lukkethed, mystik og elitisme, som har ekskluderet kvinder og været en hindring for at indoptage nye perspektiver i forskningen. ${ }^{4}$

De danske reformer står på ingen måde alene og må ses i sammenhæng med hensigterne om at homogenisere de europxiske uddannelsesstrukturer og at gøre de højere uddannelser internationalt konkurrencedygtige. Rent retorisk fastholder Bologna deklarationen fra 1999 de gamle universitetsidealer som uafhængighed og autonomi, samtidig med at formålet er at tilpasse uddannelserne til arbejdsmarkedet og erhvervslivets krav. Reformerne har både i Danmark og andre steder fået øgenavne som Dandylov og Mickey Mouse-universitet, der reflekterer, at forskning går dårligt i spænd med kommercielle interesser. Frygten går på, at der bliver for meget Mickey Mouse og for lidt Humboldt i fremtidens universitet.

Her kan der være god grund til at minde om idealerne om forskningsfrihed og autonomi. Den nodvendige fribed og udviklende ensombed, som det blev formuleret af 
den tyske videnskabsmand og politiker Wilhelm von Humboldt, er ligeså afgørende betingelser for at sikre kvalitet i den aktuelle forskning, som de var ved grundlæggelsen af det moderne dannelsesuniversitet i begyndelsen af 1800-tallet; samtidig med, at disse idealer godt kan fastholdes og udfoldes under mere kollektive former. Som det f.eks. i årtier er sket ved de berømte tværfaglige institutter for advanced studies $\mathrm{i}$ USA, Wissenschaftskollegg zu Berlin og i Norden ved SCASS $i$ Uppsala. Senest er den samme tankegang taget op i Danmark ved etableringen af Danmarks Humanistisk Forskningscenter i 2000, som har givet et stort antal forskere adgang til et års koncentreret forskning og international formidling. Centret har dertil haft en flot ligestillingsprofil blandt de ansatte stipendiater. At netop dette centers liv i skrivende stund hænger i en tynd tråd, vidner om en manglende forståelse for denne væsentlige dimension ved internationalisering og konkurrencedygtighed.

På trods af de principielle muligheder, har ligestilling og fornyelsen af forskningens indhold stort set ikke spillet nogen rolle $\mathrm{i}$ den danske debat op til vedtagelsen af de nye love for universitet og forskning. $\mathrm{Og}$ det er foruroligende. Til forskel fra den europæiske debat hvor ligestilling og køn i forskning - eller mainstreaming af køn i forskning, står centralt. Her har man for længst erkendt, at man simpelthen taber de bedste ressourcer i systemer, hvor der fortsat kun rekrutteres mænd til de ledende stillinger. I Danmark er der som bekendt stadig $90 \%$ af professoraterne, og næsten 80 $\%$ af lektoraterne som er besat med mænd.

Det store forskningsprojekt Kønsbarrierer $i$ de hojere uddannelser og forskningen har på fornem vis bragt Danmark i front hvad angår forskning og analyse af spørgsmålet om køn i akademia. Projektet har vist, at det danske universitetssystem systematisk placerer mænd i centrum og kvinder i periferien på alle niveauer indenfor uddannelse og forskning. Samtidig har projektet demonstreret problemets komplekse karakter: som udbredelsen af forkerte myter og forestillinger, konstruktionen af kønnede metaforer og koder, og effekterne af diskrimination og eksklusionspraksis på mange forskellige niveauer.

Når køn og universitet eller forskning kommer på dagsordenen i den danske forskningsdebat, er det sigende, at det sker på en måde, som ikke er på højde med denne viden og de internationale diskurser på området. Her kan man stadig møde den kønnede metafor "kvindagtiggørelse" som en betegnelse for universiteternes transformation fra eliteuniversitet til masseuniversitet. Det er ikke første gang i historien, og heller ikke nogen tilfældighed, at kvinde, bliver gjort til synonym med masse og lavstatus. Men samtidig er det en metafor, som ikke siger noget om universiteternes aktuelle situation og udfordringer og et ord, som lukker for videre refleksioner. $\mathrm{Og}$ når der $\mathrm{i}$ forskningsrådsregi bliver gjort et beskedent forsøg på - i øvrigt i fuld overensstemmelse med både danske regler og europæiske anbefalinger - at udligne den skæve professorandel ved at opslå et par professorater primært til kvinder, skal der ikke mere end et enkelt kritisk læserbrev til at få Videnskabsministeren til at tvivle på initiativets rigtighed. Jeg deltog i juni 2003 i Ligestillingsministerens cafémøde om rekruttering af flere kvinder til ledende poster i erhvervslivet og i forskningen. I erhvervslivet virker det, som om man er parat til at sætte mange ressourcer ind på at rekruttere kvinder til ledelse for at styrke den samlede virksomhed. Jeg kan vanskeligt forestille mig, at en kritisk ytring fra et forsmået mandligt lederemne, ville kunne få en Carlsberg-direktør til så meget som at ryste på hånden og de overordnede strategier $\mathrm{i}$ den anledning. På det punkt kunne universiteterne lære af den professionelle tilgang, som erhvervslivet benytter til at skabe en mere ligelig kønsfordeling på ledelsesniveau. 
I den europæiske debat, bliver den nytteorienterede retorik i Bolognadeklarationen, om forandrede behov og sammenhængen mellem samfundets krav og fremme af den videnskabelige kvalitet, eksplicit koblet til bestræbelserne på at få kvinderne med i rekrutteringspoolen. Ligesom man også erkender f.eks. kønsforskningens fornyende potentialer, både for ligestillingsdiskussionen og for samfundsmæssige forhold $\mathrm{i}$ øvigt. Det er i forlængelse heraf påtrængende, at den danske forskningsoffentlighed lige fra Videnskabsministeriet over Rektorkollegiet og forskningsrådene til de enkelte institutioner, begynder at tage denne debat til sig. Og at indsatsen bliver prioriteret og professionaliseret, som det sker mange steder i Europa. 5

Dette nummer af Kvinder, Køn \& Forskning sætter fokus på kønsforskning og ligestilling i sammenhæng med universitetet fra Humboldt til Mickey Mouse. Ærindet er at tydeliggøre og kvalificere en række af de ovenstående problemstillinger bl.a. ved at udvide synsfeltet til Norden og til Europa. Flere af bidragene i dette nummer er redigerede papers fra de sidste års konferencer på feltet. ${ }^{6}$

Harriet Bjerrum Nielsen diskuterer i essayet, Samtaler om ligestilling - indenfor, udenfor, udenom, og ind $i$ diskursen, resultater af det danske kønsbarriereprojekt. Hun efterlyser samtidig en debat om, hvordan disse resultater kan oversættes til forskningsstrategisk praksis i og udenfor institutionerne. Hvordan kan forandring overhovedet forstås? Har det danske kønsforskningsmiljø over de sidste 25 år været præget af teoripolitisk korrekthed, som har lukket for effektiv institutionalisering? spørger hun. Forslaget er, at bringe flere strategier i spil, som på en mere bevidst måde tager udgangspunkt både indenfor og udenfor den herskende diskurs.

I artiklen The Post-Modern University and the Status of Gender Studies sætter den britiske uddannelsesforsker og universitets- rektor, Peter Scott fokus på dynamikkerne i forskning, vidensproduktion og kønsforskning i overgangen fra det moderne til det postmoderne universitet og udvikler dertil nogle nyttige refleksionskategorier. Tesen er, at den aktuelle universitetspolitiske udvikling er karakteriseret af parallelle tendenser. I sin fremskrivning af disse skelner Peter Scott mellem to måder at frembringe viden på. På den ene side er der Mode I forskning - grundforskning i traditionel forstand, som er forankret på universiteterne indenfor traditionelle fagopdelinger. Forskningens kvalitet og brugbarhed bliver vurderet af fagfæller og er ikke underlagt samfundsmæssige nyttekrav. Den givne forskning kan internaliseres, er uforudsigelig og cirkulerer primært indenfor videnskabssamfundet og reflekterer ekspertise og professionelt hierarki. Den såkaldte Mode 2 vidensproduktion har andre, delvist modsatrettede kendetegn. Mode 2 vidensproduktion foregår og defineres $\mathrm{i}$ anvendte sociale, økonomiske, politiske og kulturelle kontekster. Samtidig er Mode 2 viden ikke identisk med anvendt forskning eller kommerciel forskning i traditionel forstand. Mode 2 vidensproduktion er transdisciplinær og sprænger universiteternes traditionelle faglige struktur, ligesom Mode 2 er karaktersieret af vidensdiffusion ud i samfundet eller af det, der kaldes socialt distribueret viden. Mode 2 vidensproduktion er karakteriseret ved, at processen er ligeså vigtig som produktet, og ved at være en dynamisk "problemløsning i bevægelse". Peter Scotts vurdering er, at kønsforskning har mange affiniteter til Mode 2 vidensproduktion. Som sådan har konsforskning tiden for sig som følge af den mere åbne struktur i det postmoderne - og kunne man sige post-Bologna universitet, fordi dette også vil medføre en mere inklusiv holdning på universiteterne til at inddrage og anerkende nye fleksible, tværfaglige og transfaglige måder at producere viden på.

Gabriele Griffin, britisk professor og kønsforsker, nærmer sig udviklingen af nye 
paradigmer og strukturer for vidensproduktion fra en europxisk synsvinkel i artiklen Humboldt, Mickey Mouse and Current European Reseach Programmes - or Where are the Women in all This?

Artiklen analyserer integrationen af køn og kønsforskning i det nye 6. rammeprogram for forskning, der er det sidste skud på stammen af europæiske forskningsprogrammer. Programmet har et samlet budget på 122 milliarder kroner og dækker i princippet alle forskningsområder med vægt på teknologi og naturvidenskab:

- Videnskaber vedrørende liv, genomer og bioteknologi for sundhed.

- Informationssamfund og teknologier.

- Nanoteknologi og nanovidenskaber, videns-baseret multifunktionelle materialer og ny produktions processer og devices.

- Aeronautisk rumforskning.

- Fødevarekvalitet og sikkerhed.

- Bæredygtig udvikling, globale forandringer og økosystemer.

- Borgere og styreformer i et videns-baseret samfund.

Gabriela Griffin mener, at der er en række fælles træk mellem kvinde- og kønsstudier og det europæiske projekt. Begge er transformative projekter, som ønsker at udvikle ny viden og ny forskning på et tværfagligt grundlag. Desuden rummer kvinde- og kønsforskning nye begrebsmæssige kontekster til at forstå europæiske nøgleord og institutioner, som medborgerskab, velfærdsstat, familie, race, etnicitet, såvel som integrations- og fremmedgørelsesstrategier. Sidst men ikke mindst bidrager kønsforskningen i Europa til at udvikle forståelsen af den europæiske dimension i kvinde- og kønsforskningen og til en mere reflekteret reception af den dominerende amerikanske teoriimport, som også har præget dette felt.

Det nuværende 6. rammeprogram for forskning har dog ikke gjort det lettere for kønsforskere at koble sig på. Køn synes således at være til stede overalt og ingen steder, bl.a. som følge af mainstreamingstrategien.

Alligevel råder Gabriele Griffin til, at kønsforskere prøver at spille sig ind, både med forskningsprojekter og som deltagere $\mathrm{i}$ den løbende forskningsstrategiske debat; en debat, der på forbilledlig vis er blevet initieret af Women and Science sekretariatet i EU kommissionen.

I efteråret 2002 afholdt Koordinationen for Kønsforskning en konference om kønsforskning og EU's 6. rammeprogram. Konferencen foregik på engelsk, bl.a. for at kommunikere nogle af indsigterne til de inviterede engelsksprogede oplægsholdere. Konferencen fokuserede bl.a. på blinde pletter og muligheder for at spille køn og kønsforskning ind i de foreslåede temaer i det kommende 6. rammeprogram. Kvinder, Kon \& Forskning bringer i dette nummer en række bidrag fra de danske kønsforskere Nauja Kleist, Simon Kiilerich Madsen \& Casper Bruun Jensen og Rune Gade, som hver på deres måde giver anledning til refleksion og eftertanke.

Formålet med dette nummer af Kvinder, Køn \& Forskning er som det er fremgået også at ruske op i den danske debat om kønsforskning og ligestilling i akademia. Det gør vi bl.a. ved at bringe en række aktuelle debatindlæg, som tager temperaturen på disse spørgsmål i Danmark. Ning de Coninck-Smith efterlyser en større bevidsthed om køn i universiteternes profiler og mener, at det virkelige ligestillingsproblem ligger i kvindernes manglende muligheder for at få fast ansættelse. Bente Rosenbeck gennemgår de sidste års bevillingspraksis i forskningsrådene ud fra en ligestillings- og kønsprofil.

Endelig præsentes nogle fremadrettede aktiviteter fra Norden og fra Europa.

Solveig Bergman formidler resultaterne fra en omfattende international evaluering af kvinde- og kønsforskningen i Finland. Kønsforskning kom senere i gang i Finland 
end i det øvrige Norden, men har haft en blomstringstid i 1990erne.

Kirsten Gomard og Kirsten Reisby opsummerer nogle diskussioner fra en nyligt afholdt europæisk konference om ligestilling i akademia: The Third European Conference on Gender in Higher Education. Konferencen vidner om, at emnet er ved at bide sig fast både som praksis og som forskningstema i den europæiske forskningsoffentlighed.

Billedserien i dette temanummer præsenterer ti af Danmarks kvindelige professorer gennem tiden. I udvælgelsen af billederne er der lagt vægt på faglig spredning. Tankevækkende er flere af oplysningerne; f.eks. at den første danske kvindelige professor blev udnævnt i 1946, at den første kvindelige professor blev optaget i Videnskabernes Selskab i 1968, at det første professorat i litteratur til en kvinde blev tildelt i 1999 og at en høj grad af innovation har præget professoraterne - fagligt såvel som privat.

Biografierne er hentet fra Dansk Kvindebiografisk Leksikon og indsamlet af forskningsbibliotekar Eva Lous og konsulent Jytte Larsen. Hvor intet andet er anført er billederne fra Det Kongelige Biblioteks Billedsamling.

\section{Temaredaktør \\ Hilda Rømer Christensen}

\section{NOTER}

1. Humboldt, W: Schriften zur Politik und zum Bildungswesen. (Werke IV) Stuttgart. Darmstadt Wisssenschaftliche Buchgesellschaft, ( 1809) 1964. her citeret fra Hammershøj,Lars Geer, (2003): Selvdannelse og socialitet. Forsøg på en konstruktivistisk orienteret socialanalytisk samtidsanalyse. Sociologisk Institut. Ph.d. serie nr. 22. København: 64
2. "European Higher education institutions, for their part, have accepted the challenge and taken up a main role in constructing the European area of higher education, also in the wake of the fundamental principles laid down in the Bologna magna Charta Universitatum of 1988. This is of the highest importance, given that Universities' independence and autonomy ensure that higher education and research systems continuously adapt to changing needs, society's demands and advances in scientific knowledge". (The Bologna Declaration of 19 June 1999. Joint Declaration of the European Ministers of Education.)

3 . Lov om universiteter (universitetsloven) vedtaget den 8. maj, 2003 samt lov om forskningsrådgivning m.v. vedaget den 4. juni, 2003.

4. Griffin, Gabriele and Braidotti, Rosi, (2002): Thinking Differently. A reader in European

Women's Studies. Zed Books. London and New York. 2002: 3ff

5. Bl.a. i følgende rapporter:

Osborn, Mary, Teresa Rees et al. (eds.) (2000): Science Policies in the European Union: Promoting excellence through mainstreaming gender equality. A report from the ETAN Network on Women and Science, Luxembourg: Office for Official Publications of the European Communities.

Maxwell, Linda, Slavin, Karen \& Young, Kerry (eds.), (2002): Gender \& Research, Brussels, 8-9 November 2001, European Commission, Directorate-General for Research, C5, Women and Science, Luxembourg, Office for Official Publications of the european Communities

Rees, Teresa (2002): National policies on women and science in Europe. A report from The Helsinki Group on Women and Science, Luxembourg: Office for Official Publications of the European Communities.

6. Peter Scotts artikel bygger på indlæg ved konferencen: Status, Strategi, Perspektiv i dansk Kønsforskning. IT og Forskningsministeriet i samarbejde med Koordinationen for Kønsforskning, Københavns Universitet, marts 2001. Gabriele Griffins artikel er baseret på indlæg ved konferencen Gender Makes a Difference. Gender Studies at the Cutting Edge of European Research. Københavns Universitet November 2002.

Se rapport side 62 . 


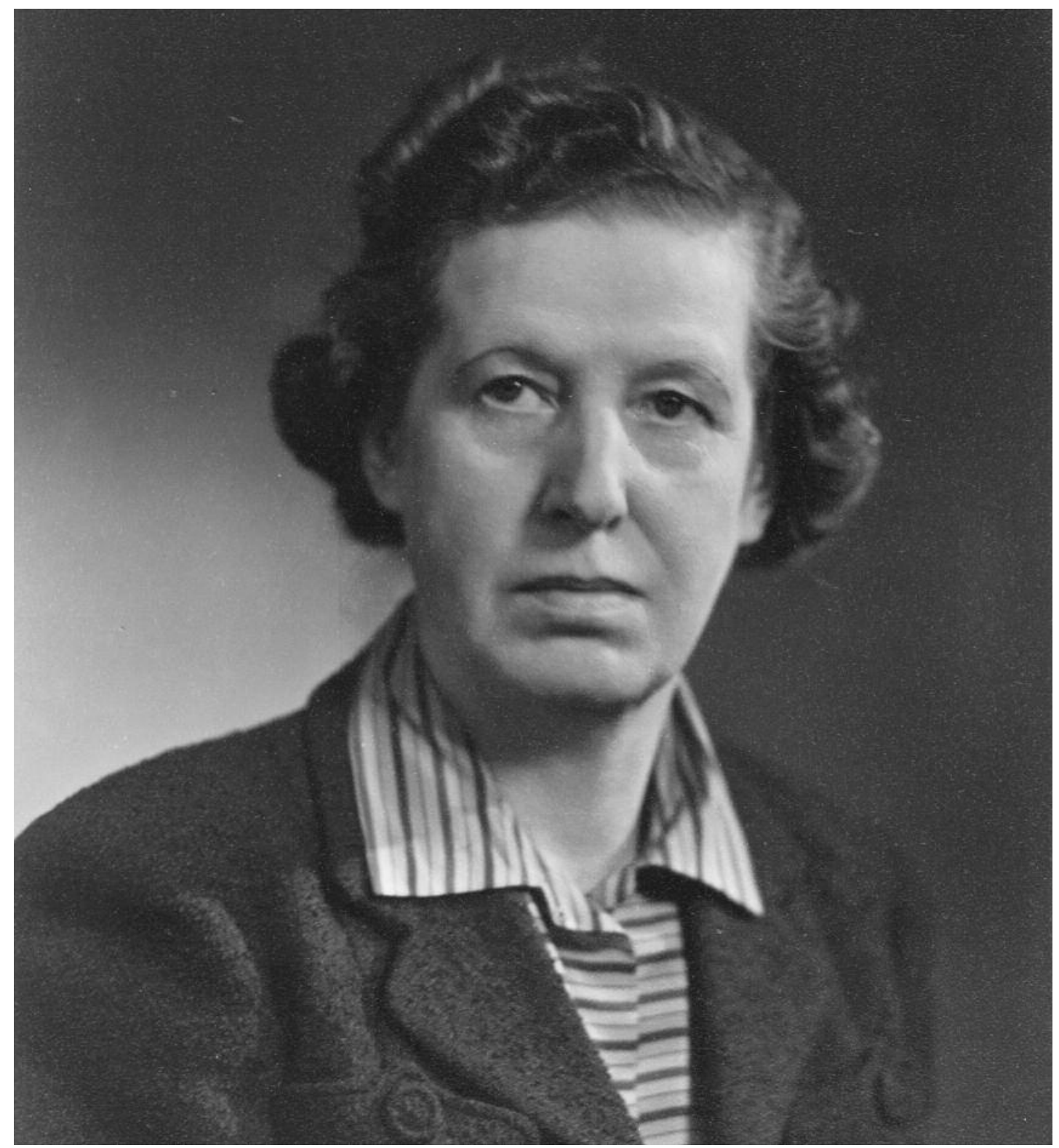

\section{AsTRID FRIIS (1893-1966)}

Astrid Friis er Danmarks forste kvindelige professor. 1946-64 professor $i$ historie ved Københavns Universitet.

Som professor koncentrerede Astrid Friis sig om undervisning og administration. Hun var ikke kvindesagligt aktiv, selv om hun mente, at konnet havde veret udslagsgivende, da hun blev forbigået ved besettelsen af et professorat ved Aarhus Universitet $i$ 1939. Videnskabernes Selskab forblev lukket land for hende - et forslag om optagelse af landets forste kvindelige professor blev afvist $i 1949$.

Astrid Friis giftede sig aldrig, men levede sammen med sin søster Anne Friis, der var magister $i$ engelsk. 